\title{
TUAN GURU DALAM PUSARAN KONTESTASI POLITIK DI LOMBOK TENGAH (STUDI MOTIF DAN AKSI POLITIK)
}

\author{
Muhammad Amrillah \\ IAI Hamzanwadi Lombok Timur \\ muhammadamrillah@iaihnw-lotim.ac.id
}

\begin{abstract}
Tuan guru's character in the Lombok Community encourages Tuan Guru to be involved in practical politics so that it has an impact on da'wah activities. This study uses a descriptive qualitative approach, data collected by the method of observation, documentation and interviews. This study resulted in a fact that the involvement of the guru - Tuan Guru in Praya Subdistrict, Central Lombok in politics was motivated by their capacity and role in society, but then the role shifted towards "political oriented". The role of the teacher is no longer only as a preacher but shifts as a practical political actor who is feared to make da'wah as an opportunity to carry out political socialization that is full of political interests. The reasons for the teacher to enter into practical politics are: Channeling aspirations in the community, develop Islamic institutions, enforce the commandments of good and evil, building political participation and education for the community.
\end{abstract}

Keywords: Da'wah, Politics, Tuan Guru.

\begin{abstract}
Abstrak
Ketokohan tuan guru di Masyarakat Lombok mendorong tuan guru banyak terlibat dalam politik praktis sehingga berdampak pada aktivitas dakwah. Penelitian ini menggunakan pendekatan kualitatif deskriptif, data dikumupulkan dengan metode observasi, dokumentasi dan wawancara. Hasil penelitian ini menunjukkan bahwa keterlibatan tuan guru - tuan guru di Kecamatan Praya Lombok Tengah dalam politik dilatarbelakangi oleh kapasitas dan perannya dalam masyarakat, namun kemudian peran bergeser kearah "political oriented". Peran tuan guru tidak lagi hanya sebagai muballigh akan tetapi bergeser sebagai actor politik praktis yang dikhawatirkan menjadikan dakwah sebagai peluang melakukan sosialisasi politik yang sarat dengan kepentingan politik. Adapun alasan-alasan tuan guru terjun kepolitik praktis adalah: Menyalurkan aspirasi di masyarakat, mengembangkan lembaga-lembaga islam, menegakkan amar makruf nahi mungkar, membangun partisipasi dan pendidikan politik terhadap masyarakat.
\end{abstract}

Kata Kunci: Dakwah, Politik, Tuan Guru. 
Komunike, Volume XIII, No. 1 Juni 2021

\section{A. PENDAHULUAN}

Sebagai daerah dengan kultur keagamaan yang kuat, Lombok dikenal sebagai Pulau Seribu Masjid. ${ }^{1}$ Keberadaan masjid ini di samping sebagai identitas juga sebagai sentral pusat dakwah dan penyelenggaraan ritual keagamaan, seperti sholat, acara maulid, isro' mi'raj dan hari-hari besar keagamaan lainnya. Semua acara keagamaan diisi oleh pengajian (ceramah) yang disampaikan oleh Tuan Guru. Tuan Guru ${ }^{2}$ - sebutan untuk tokoh agama di Lombok - memegang otoritas yang kuat dalam mengemban tugas dakwah. Aktifitas dakwah memiliki peranan yang cukup signifikan dan strategis dalam proses penyebaran ajaran agama Islam. Posisi ini pun yang menjadikan tuan guru menjadi strategis dalam mengorganisasi masa sehingga berpengaruh terhadap kedudukan sentral tua guru di masyarakat.

Kehadiran dakwah sebagai
ikhtiar membumikan atau men-

\footnotetext{
${ }^{1}$ Fahrurrozi, Budaya Pesantren Di Pulau Seribu Masjid, Lombok, KARSA: Jurnal Sosial dan Budaya Keislaman Vol. 23 No. 2, Desember 2015: 324-345. hal ini menjadi salah satu faktor yang menjadikan peran dan kedudukan tuan guru begitu di masyarakat Lombok.

2 Ahsanul Rijal, Politik Tuan Turu Versus Politik Media "Pilpres 2019 di Lombok "Antara Dakwah dan Politik. Volume 16, No. 2, Juni 2019. 21. Jamaludin, Sejarah Sosial Islam di Lombok Tahun 1740-1935. h. 134-139
}

transformasikan nilai-nilai ajaran Islam diharapkan mampu memberikan solusi terhadap berbagai permasalahan kehidupan manusia. Dewasa ini, permasalahan yang dihadapi objek dakwah semakin berat dan kompleks akibat arus kemajuan zaman yang ditandai pesatnya perkembangan ilmu pengetahuan dan teknologi, serta dibarengi dengan sistem globalisasi. Kondisi ini tentu menjadi tantangan bagi dakwah menegakkan amr ma'ruf dan nahi munkar. ${ }^{3}$

Pasca era Orde Baru, kran kebebasan politik dibuka selebar lebarnya. Imbas dari itu, pemilihan presiden melibatkan partisipasi rakyat secara langsung. Di samping itu pemilihan gubernur, bupati, Kepala Desa bahkan Kepala Dusunpun melibatkan partisifasi seluruh masyarakat. Sehingga berdampak komplek dalam kehidupan sosial masyarakat. Hal itu juga berdampak pada posisi dan peran tuan guru. Dahulu tuan guru menjadi tempat bersandar terkait sosial keagamaan, kini bisa menjadi magnet politik.

$$
\text { Kondisi semacam ini }
$$
"menguntungkan" posisi tuan guru, sebagai orang yang dihormati di tengah

${ }^{3}$ Winengan, Seni Mengelola Dakwah, (LP2M UIN Mataram), 2018, iii 
tengah masyarakat, tuan guru seakan menjadi referensi keputusan politik. Hal ini menyebabkan politisi politisi melakukan pendekatan dengan tuan guru sebagai "mitra" untuk mensukseskan misi politiknya. Tak sedikit pula tuan guru yang terjun langsung ke dunia politik, jika pun tidak, maka keluarga-keluarga tuan guru ikut memanfaatkan momentum ini.

Realitas tersebut sedikit tidak berpengaruh terhadap aktivitas dakwah tuan guru. Yang paling umum terlihat adalah bergesernya konten ceramah tuan guru. Materi ceramah seharusnya tentang syariah, ibadah dan akhlak dan topik keagamaan lainnya. Maka keterlibatan tuan guru dalam dunia politik materi ceramah lebih dominan sosialisasi politik. Dengan demikian dakwah tuan guru terkontaminasi dengan kepentingan politik, materimateri pengajian terkooptasi oleh kepentingan politik kelompok tertentu. Yang lebih parah terjadi adalah politisasi agama, dimana ayat dan hadits "ditafsirkan" untuk mendukung kelompok tertentu. Pengajian sudah tidak murni kajian keagamaan akan tetapi wadah untuk sosialisasi politik.

Seringkali tuan guru juga sudah mempunyai calon yang diusung sejak awal untuk memperjuangkan aspirasi politiknya, biasanya ini berasal dari kalangan keluarga tuan guru. Banyak pula para tuan guru yang tidak mengusung calon dari keluarga, dan disinilah peluang bagi para politik untuk melakukan pendekatan kepada tuan guru dengan tujuan menggaet suara jamaah. Biasanya terjadi kesepakatan antarcaleg dan tuan guru terkait hal ini. Biasanya caleg mengimingi tuan guru dengan janji-janji politik dan bagi yang bermodal bahkan memberikan sejumlah materi. Adapaun bagi para caleg yanglagi menjabat biasanya tuan guru diberikan bansos dalam bentuk bahan bangunan dan sejumlah dana.

Hal inilah yang terjadi di Lombok Tengah khususnya di Kecamatan Praya. Kecamatan Praya dengan jumlah pondok pesantren yang cukup signifikan melahirkan tuan guru dengan berbagai coraknya pemikiran dan gaya dakwahnya. Tuan guru berkiprah di masyarakat membina masyarakat melalui majlis-majlis ta'lim. Jamaah pada umumnya mempunyai tingkat ketaatan yang kuat kepada tuan guru, sehingga sering tuan guru merelasikan antara ketaatan jamaah dengan hasrat politiknya. Posisi semacam itu membawa tuan guru 
sebagai magnet politik sehingga telah menjadikan konstelasi politik begitu dinamis dan tarik menarik antar kepentingan politik bahkan antar tuan guru.

Hampir semua tuan guru terlibat dalam politik praktis, baik sebagai calon maupun pendukung terhadap beberapa politisi. Politik praktis merupakan tindakan politis untuk memperoleh kekuasan/jabatan dan pemerintahan. Melalui politik praktis ini para tuan guru kemudian menjadi aktor politik praktis bermodalkan kapasitas dirinya dan loyalitas jamaahnya, keterlibatan mereka dalam politik praktis sedikit tidak berdampak terhadap peran dan fungsinya ditengah-tengah masyarakat.

Tuan guru yang awalnya membina masyarakat tanpa tendensi apapun, setelah menjadi aktor politik praktis semua kegiatan ketuan guru annya sangat rawan diikuti oleh tendensi politik. Di sisi lain, kebanyakan tuan guru dalam terjun ke dunia politik dengan tujuan untuk menegakkan amar ma'ruf nahi munkar. Konsep amar ma'ruf nahi munkar ini diletakan dalam pengertian yang luas, yaitu pengawasan dan evaluasi. Dalam pandangan tuan guru, konsep ini memiliki peran signifikan, karena dalam kenyataannya tatanan sosial-politik yang ada banyak yang tidak sejalan dengan ajaran agama.

Karena itulah para tuan guru merasa perlu untuk terjun ke dalam dunia politik untuk mewujudkan kontrol kekuasaan yang sewenang-wenang dan menyimpang dari aturan moral, hukum, maupun aturan agama. Selain itu, konsep amar ma'ruf ini hendaknya juga dipahami dalam cakupan dan pengertian yang luas, yaitu mewujudkan perbaikan sistem pendidikan, penegakan supremasi hukum, meningkatkan kesejahteraan rakyat, dan memprioritaskan pembangunan bagi rakyat. Meskipun demikian, masuknya para kiai ke dunia politik tidak selalu membawa implikasi yang menggembirakan. Misalnya pesantren yang tak terurus dengan baik, ataupun fungsi-fungsi sosial-keagamaan kiai yang sedikit banyak terdegradasi.

Hal ini merupakan salah satu latar belakang, mengapa tuan guru sebagai pemimpin informal tampil sebagai aktor politik paling menentukan dalam dinamika politik di Nusa Tenggara Barat dan Lombok pada khususnya. Rentetan even politik yang sudah berlangsung selalu menghadirkan pertarungan kekuatan tuan guru. 
Misalnya pemilihan umum legislatif di Kabupaten Lombok Tengah pada tahun 2004 yang menyuguhkan fragmentasi pilihan politik jamaah terhadap calon anggota legislatif sangat mudah dilacak dengan afiliasi politik tuan guru.

Keterlibatan Tuan guru dalam politik praktis, sampai sejauh ini memang terjadi tarik-menarik pendapat, antara kelompok yang mengabsahkan Tuan guru berpolitik dengan kelompok yang menentang dengan keras Tuan guru terlibat dalam politik. Kelompok pertama mengasumsikan bahwa Tuan guru bagaimanapun juga merupakan entitas yang memiliki hak dan aspirasi politik seperti halnya warga Negara yang lain. Sedangkan kelompok yang kedua mengkritik dengan keras, berdasarkas asumsi bahwa keterlibatan Tuan guru dalam politik lebih banyak mendatangkan kerugian daripada keuntungan yang bisa didapatkan. Hal ini berkaitan dengan realitas politik yang oleh banyak kalangan dianggap “kotor”. Sehingga ketika Tuan guru dan pesantren terlibat dalam politik akan terseret kedalam dunia yang "kotor" pula. $^{4}$

\footnotetext{
${ }^{4}$ H. Sadi, Kiai Dan Politik: Mengintip Motif Kiai Nu (Nahdlatul Ulama) Dalam Pemilu 2009 Di Glenmore Kabupaten Banyuwangi Khazanah Pendidikan Jurnal Ilmiah Kependidikan, Vol. X, No. 1 (September 2016), 32
}

Munculnya perbedaan pendapat tentang bagaimana peran politik Tuan guru di masyarakat, menjadi isu yang debatable dan tak akan pernah selesai. Masing masing akan terus menerus memperkuat argumentasi kelompoknya. Meskipun terdapat kontroversi yang berkepanjangan mengenai keterlibatan Tuan guru dalam Politik, sesungguhnya keterlibatan Tuan guru dan pesantren tidak dapat dihindari. Intensitas Tuan guru dan bentuk keterlibatan Tuan guru dalam politik bisa bermacam-macam, baik secara langsung maupun tidak langsung, sebagaimana dapat dilihat melalui keterlibatan Tuan guru dalam momen-momen politik yang penting seperti Pemilihan Umum (Pemilu), Pemilihan Presiden (Pilpres), atau pemilihan umum kepala daerah (Pemilukada).

Munculnya tuan guru sebagai top leader dengan cara di atas diterima begitu saja oleh masyarakat karena hal itu dianggap sebagai suatu kelaziman. Hal ini terwujud karena adanya penghormatan dan kharisma yang tinggi pada sosok tuan guru serta adanya tradisi dalam masyarakat dan pelaku politik di Praya, bahwa tuan guru adalah sosok yang mempunyai kemampuan dan akseptabilitas dalam memimpin. 
Di samping persaingan tuan guru antar kelompok keagamaan, di Praya juga terjadi persaingan interen kelompok yang menjurus pada perebutan posisi kedudukan strategis seperti jabatan ketua dan sekeretaris. Persaingan tuan guru dalam bidang politik ini seringkali membawa implikasi terjadinya pertentangan pada tingkat bawah masyarakat (grass root) yang dengannya masyarakat terpecah dalam berberapa kelompok yang mengatasnamakan agama.

Dengan kata lain, pola-pola kepemimpian tuan guru di pesantren terbawa dan mewarnai dalam kepemimpinan mereka dalam bidang politik. Di lain pihak, tuan guru menginginkan agar kepentingannya diperjuangkan di samping keinginan mereka untuk dapat mengontrol kekuasaan-kekuasaan politis. Disinyalir ada kepentingan politik dalam dakwah tuan guru, ada kekuatan kepentingan politik dibalik aktivitas-aktivitas pengajian tuan guru. Tidak jarang para tuan guru melakukan doktrin politik kepada jamaahnya dalam pengajianpengajian untuk menguatkan eksistensinya di dunia politik, bahkan sering kali konten-kotens politik mengkooptasi majlis-majis taklim.
Sehingga mimbar majlis taklim berubah orientasi menjadi mimbar politik. Penelitian ini mengeksplorasi, sejauh mana dakwah dalam hegemoni politik yang terjadi menjelang Pemilihan Legilatif 2019. Penelitian ini dilakukan di Kecamatan Praya Lombok Tengah sebagai daerah yang cukup heterogen pandangan politiknya yang diwakili oleh para tuan guru.

\section{B. LITERATURE REVIEW}

Kajian tentang politik dan dakwah telah banyak diteliti, beberapa penelitia yang terkait dengan itu adalah sebagai berikut:

Andy Darmawan, melakukan penelitian tentang Dialektika Dakwah, Politik dan Gerakan Keagamaan Kontemporer (Telaah Pemikiran Nasir al-Din al-Albani dan Pengaruhnya Terhadap Pembentukan Salafy Kontemporer). Kajian ini menelaah tentang dialektika dakwah, politik dan gerakan keagamaan kontemporer khususnya aliran Salafy yang memiliki penganut di berbagai belahan dunia. Aliran Salafy, ternyata terbukti mendayagunakan pintu dakwah dan politik di dalam melancarkan visi dan misi Salafy guna membangun kekuatan jamaah yang militan. 
Ahmad Asroni dkk, melakukan penelitian dengan topik Dakwah dan Politik: Menakar Kontribusi Organisasi Islam Sayap Partai Politik Bagi Masyarakat Muslim Yogyakarta. Penelitian ini dilatarbelakangi oleh fenomena menjelang pemilu, Seperti telah menjadi tradisi, menjelang Pemilu tak sedikit partai politik di Indonesia ramai-ramai mendirikan organisasi Islam. Dua dari sekian banyak partai politik yang mendirikan organisasi Islam sayap partai politik (parpol) adalah Partai Golkar dengan mendirikan Majelis Dakwah Islamiyah (MDI) dan Pengajian Al-Hidayah serta PDI-P dengan membentuk Baitul Muslimin Indonesia (Bamusi).

Agus Dedi Putrawan melakukan penelitian dengan topik Dekarismatisasi Tuan Turu Di Pulau Lombok Nusa Tenggara Barat. Penelitian ini membahas tentang kharisma tuan guru di pulau Lombok Nusa Tenggara Barat yang semula kuat kemudian memudar karena berbagai faktor. Selain menjadi guru dan pemimpin pesantren, sekaligus pemilik, menempatkan para tuan guru sebagai pemegang kekuasaan mutlak di lingkungan pesantrennya. Karisma tuan guru akan memudar ketika ia keluar melewati wilayah teritorialnya sendiri atau basis legitimasi (akuan karisma).

Ketiga penelitian di atas, meskipun sama-sama mengkaji tentang dakwah dan politik, akan masingmasing mempunyai kekhasan dan karakteristik yang berbeda. Demikian juga penelitian ini focus pada kiprah politik tuan guru di Lombok Tengah.

\section{METODE PENELITIAN}

Penelitian ini merupakan penelitian kualitatif deskriptif yaitu penelitian yang dimaksudkan untuk memberikan data seteliti mungkin tentang manusia atau keadaan dan gejala-gejala lainnya. pendekatan yang digunakan dalam penelitian ini adalah pendekatan fenomenologi. Pendekatan fenomenologi merupakan tradisi penelitian kualitatif yang berakar pada filosofi dan psikologi, dan berfokus pada pengalaman hidup manusia (sosiologi). Ruang lingkup penelitian ini mencakup latar belakang keterlibatan tuan guru dalam politik dan bentuk keterlibatannya dalam politik. Penggalian data dilakukan dengan metode observasi, deept interview dan dokumentasi.

Dalam menganalisa data dan materi yang disajikan dalam penelitian ini, dipergunakan dua metode yaitu 
metode deduktif dan induktif. Metode deduktif merupakan salah satu metode berfikir yang berangkat dari - yang umum, dalam ini teori, dalil, hukum, kaidah-kaidah kemudian dianalisa ke arah yang lebih khusus. Sedangakan Metode induktif yaitu cara berfikir yang berangkat dari fakta-fakta dan peristiwa yang khusus dan kongkrit, kemudian ditarik generalisasi yang bersifat umum.

\section{HASIL DAN PEMBAHASAN}

Kiprah Politik Tuan Guru Dapat dikatakan, semua tuan guru yang menjadi responden terlibat dalam politik praktis di Praya seperti pemilihan gubernur, Bupati dan pemilihan calon anggota legislatif. Tuan guru selalu terlibat baik sebagai peserta maupun pendukung. Beberapa nama tuan guru yang terlihat berperan cukup signifikan dalam pemilihan anggota legislatif diantaranya sebagai berikut:

TGH. Fadly Fadil Thohir merupakan pimpinan Pondok Pesantren Yayasan Tohiriyah Fadiliyah Bodak Kecamatan Praya Lombok Tengah. Kiprah politiknya kerap mewarnai dunia perpolitikan secara signifikan. Salah satu kiprah politiknya adalah dapat mengantarkan Suhaili FT, sebagai Bupati Lombok Tengah dua periode. TGH. Fadly Fadil Thohir lebih dominan sebagai pendukung dari pada sebagai pemain, mengingat pemain yang didukung adalah keluarga dekat. Pada tahun 2019, TGH. Fadly Fadil Thohir memberikan dukungan kepada keluarga dekat yang mencalonkan diri sebagai calon anggota legislatif baik dari tingkat kabupaten, provinsi dan pusat. Selama ini arah dukungan diberikan melalui Partai Golkar dimana keluarganya banyak menyalurkan aspirasi politiknya.

TGH. Makmur Shaleh tidak memiliki pondok pesantren, akan tetapi ia membina beberapa majlis taklim yang cukup potensial jika diarahkan ke politik. Pada kenyataannya TGH. Makmur Sholeh memang sering terlibat dalam politik praktis. Pernah menjadi calon Bupati Lombok Tengah Pada Tahun 2009, namun tidak meraih suara secara signifikan sehingga terpental dari kontestasi pilbup loteng. Keterlibatan TGH. Makmur Shaleh dalam politik praktis lebih sering sebagai pendukung terhadap calon. Posisinya sebagai tuan guru yang banyak mengelola majlis taklim, menjadikan ia banyak dilirik oleh para politisi untuk melakukan sosialisasi politik, tentu tak lepas "konsekwensi" politik.

TGH. Jamaluddin merupakan calon anggota legislatif tahun 2019 dari 
Partai Demokrat. TGH Jamaluddin ketika mencalonkan diri sebagai calon anggota legislatif provinsi NTB pada tahun 2019, ia juga sedang menjabat anggota DPRD Lombok Tengah periode 2014-2019.

TGH. Fachruddin merupakan pimpinan Pondok Pesantren Modern Sabulussalam Gerunung Praya. Pada Tahun 2019 istrinya mencalonkan diri sebagai calon anggota legislative Provinsi Nusa Tenggara Barat dapil 7 melalui Partai Demokrat.

TGH. Syatibi merupakan pimpinan Pondok Pesantren $\mathrm{Al}$ Hannaniyah Panji Sari Praya. Ia cukup aktif dalam berpolitik. Keterlibatanya dalam politik lebih dominan sebagai pendukung pada calon tertentu. Biasa kontrak politiknya diwujudkan dalam bentuk sumbangan calon terhadap pondok pesantren berupa bantuan pembangunan pondok pesantren. Dukungan yang diberikan pada umumnya menggunakan pendekatan personal bukan kepartaian,

TGH. Ijazi merupakan salah satu tuan guru yang cukup berpengaruh di Praya. Pondok pesantren yang ia pimpin yaitu Pondok Pesantren Sa'adatuddarain merupakan pondok pesantren yang sedang berkembang dan mendapat respon positif dari masyarakat, Keterlibatannya dalam politik praktis lebih dominan sebagai pendukung terhadap calon. Pada tahun 2019, keluarga dekatnya mencalonlan diri sebagai calon anggota legislatif daerah Lombok Tengah melalui Partai Hanura dan mendukung salah satu calon DPD RI.

TGH. Shabri Azhari merupakan pimpinan Pondok Pesantren Darul Muhibbin NW Mispalah Praya. Pondok Pesantren yang cukup terkemuka dan senior di Kota Praya, dalam setiap momen politik selalu berpartisifasi dalam politik. Sebagai pimpinan pondok pesantren yang berafiliasi ke organisasi Nahdlatul Wathan, arah politiknya selalu merujuk pada kebijakan politik organisasi. Pada tahun 2019 kebijakan politik Nahdlatul Wathan berafiliasi ke Partai Hanura, maka keberpihakan politik TGH. Shabri Azhari juga merujuk pada kebijakan organisasi yaitu Partai Hanura.

TGH. Zainal Arifin merupakan pimpinan Pondok Pesantren Munirul Arifin NW Praya, yang merupakan pondok pesantren yang sedang berkembang di Kota Praya. Secara pribadi, TGH. Zainal Arifin tidak berpolitik, tapi secara kelembagaan dan 
organisasi TGH. Zainal Arifin bermain di belakang layar. Sebagai pondok pesantren NW, kebijakan politik TGH. Zainal Arifin tidak pernah lepas dari kebijakan politik pimpinan pusat Nahdaltul Wathan. Pada tahun 2019, Putranya sulungnya mencalonkan diri sebagai calon anggota legislatif daerah Lombok Tengah, tentu atas restu dan dukungan ayahandanya. Lebih dari itu, beberapa pengurus pondok pesantren yang ia pimpin, juga mencalonkan diri sebagai calon anggota legislatif, indikasi ini menambah daftar caleg dari kalangan pondok pesantren.

\section{Motif Kiprah Politik Tuan Guru}

Dengan berlakunya pemilu yang melibatkan partisifasi masyarakat secara masal secara langsung membawa dampak yang cukup serius terhadap perilaku politik di tingkat lokal. Para aktor politik lokal tiba-tiba mendapatkan arena bermain yang cukup luas untuk menyalurkan bakat-bakat politik mereka secara bebas. Tentu saja banyak yang tergagap dengan perubahan mendadak ini. Elit agama (Tuan guru/tuan guru) termasuk kelompok yang relitif belum siap menyikapi terbukanya kesempatan politik di tingkat lokal ini. Tampilnya para kandidat calon dalam arena pilkada langsung mau tidak mau harus menyeret dukungan dari berbagai kekuatan yang memiliki basis massa yang kuat.

Namun, orientasi pragmatis seperti tidaklah mudah dilihat dan diteliti. Hal ini dikarenakan, Tuan guru adalah figur sentral masyarakat, dan jika Tuan guru melakukan hal-hal yang sedikit saja melenceng dari norma masyarakat, ia akan dijauhi oleh masyarakat. Maka, dalam berpolitik Tuan guru tidak akan pernah menonjolkan hal tersebut. Namun, banyak Tuan guru tidak menampik kemungkinan jika ada calon yang memberikan sumbangan dana atas jerih payahnya selama ini.

Orientasi ideologis adalah terjunnya Tuan guru ke gelanggang politik merupakan panggilan hati untuk mengawal proses demokratisasi agar tercipta masyarakat yang aman, tentram, adil dan makmur. Atau dengan bahasa agama, masuknya Tuan guru ke ranah politik sebagai bagian amar ma'ruf nahi munkar. Dan orientasi inilah yang paling menonjol dalam setiap aktifitas Tuan guru dalam ranah politik.

Politik sangat erat kaitannya dengan masalah kekuasaan, pengambilan keputusan, kebijakan publik dan alokasi atau distribusi. 
Aspirasi ummat Islam diartikulasikan baik melalui jalur politik maupun non politik. Sebelum dan diawal periode orde baru, terdapat kecenderungan yang kuat dikalangan para pemimpin muslim bergabung dalam kancah poltik, sehingga mereka mengidetifikasikan perjuangan Islam dengan partai politik Islam.

Perkembangan politik praktis di Indonesia membawa sejumlah tuan guru terjun langsung maupun tidak langsung dalam kancah perpolitikan di Indonesia. Aspirasi politik tuan guru dimanfaatkan partai politik di tingkat nasional maupun lokal dalam setiap pemilu. Alhasil, tuan guru dihadapkan pada dunia politik praktis yang sarat dengan ketidakpastian dan kepentingan. Hampir di setiap partai politik, figur tuan guru menjadi bagian yang tidak terpisahkan. Dunia politik tidak lagi menjadi sesuatu yang tabu, bahkan seakan-akan, telah menjadi sesuatu yang harus direbut dan diraih. Tuan guru telah mendapatkan lahan garapan yang baru, setelah sebelumnya lebih banyak mengurus masalah pesantren dan masyarakat secara langsung, kini telah beralih mengurus dunia politik yang secara otomatis telah menyedot energi para tuan guru.
Posisi inilah yang kemudian telah "menyeret" posisi tuan guru dari dunia pesantren menjadi dunia politik. Ada beberapa alasan yang peneliti temukan dilapangan mengapa tuan guru harus terlibat dalam politik.

a. Pengaruh di Masyarakat

Ada beberapa tuan guru yang peneliti temukan tidak begitu antusias dengan dunia politik, akan tetapi mengingat posisinya yang terpandang di masyarakat membuat beberapa jamaahnya mendorongnya untuk maju di pemilihan umum legislatif. Di samping itu, tawaran dari partai politik berdatangan, pada umumnya tawaran dari partai politik datang berdasarkan pantauan bahwa tuan guru yang bersangkutan mempunyai jamaah yang banyak dan memiliki kapasitas yang layak sebagai anggota legislatif.

Berdasarkan pantauan peneliti, tuan guru tersebut memang tidak begitu antusias dengan politik, dan dalam pencalonannya tidak terlihat upayaupaya yang signifikan untuk memenangkan perhelatan pemilihan umum legislatif dan pada kenyataannya, perolehan suaranya memang jauh dari angka cukup. Tuan guru tersebut lebih fokus mengembangkan majlis ta'lim 
dan pondok pesantren nya yang baru beberapa tahun beroperasi.

Pada pemilihan umum legislatif 2019, peneliti banyak melihat kalangan tuan guru menjadi calon legislatif. Baik tuan guru senior maupun tuan guru yunior. Partai politik kerap kali mengincar tuan guru sebagai calon anggota legisatif karena melihat bahwa tuan guru mempunyai banyak peluang untuk mendulang suara, karena itulah tuan guru banyak direkrut sebagai calon anggota legislatif. Ilmu agama yang dimiliki membuatnya dihormati dan disegani masyarakat. Tentu saja, imbauan yang dikeluarkan memikiki kekuatan. Termasuk untuk mendukung dirinya merasakan kursi empuk wakil rakyat.

Keberadaan tuan guru sebagai calon dari anggota legislatif tersebar dari beberapa partai mulai dari partai nasionalis seperti gerindra, demokrat dan PAN. Tuan guru sebagai calon anggota legislatif akan banyak ditemukan di partai partai Islam seperti PPP, PKB, dan PKS. PKS sendiri, untuk DPRD NTB mendaftarkan bacaleg dengan kekuatan penuh sebanyak 65 orang. Sebanyak 10 tuan guru, tersebar di berbagai daerah pemilihan (dapil).

b. Menerapkan Syariat Islam
Dalam Berpolitik banyak tuan guru yang berkeyakinan bahwa politik merupakan bagian dari syariat islam sebagai bentuk universalitas dan komprehensivitas Islam. Sejatinya Islam dan politik tidaklah dapat dipisahkan. Islam adalah satu satunya agama yang mempunyai pengaturan dalam kehidupan untuk manusia. Islam tidak hanya mengatur urusan ibadah manusia kepada penciptanya, tapi dia mengatur urusan manusia dengan dirinya sendiri maupun dengan sesamanya.

Islam adalah agama yang mempunyai solusi bagi permasalahan manusia. Dia tidak melulu mengurusi masalah akhirat, tapi dia memberikan arahan dan tatacara manusia menjalankan kehidupannya agar sesuai dengan aturan sang pencipta se agai bekal untuk akhiratnya.

Oleh karena Islam adalah sebuah jalan hidup, adalah sebuah ideologi, maka Islam mengurusi semua aspek kehidupan, termasuk urusan politik. Islam tidak akan pernah bisa jauh dari politik, yang tentu politik Islam.

Dalam bahasa arab, politik dikenal dengan assiyasah yang berarti mengurus. Karena Islam bukan hanyaagama ritual, tetapi aturan hidu maka politik dalam Islam adalah dalam 
konteks mengurusi urusan umat. Baik dalam pemerintahan, pengaturan kepemilikan, kesejahteraan umat dan lain lain.

Pemahaman semacam ini banyak diyakini oleh para tuan-guru sehingga menjadikan politik itu sebagai sebuah ibadah. PKS merupakan salah satu partai yang menganut ideologi semacam, dimana politik adalah bagian dari syariat, sehingga berpolitik adalah menjalankan syariat.

Dalam pengamatan peneliti, PKS memang banyak merekrut tuan guru sebagai calon anggota legislatifnya, dan untuk memastikan berjalannya politik sesuai dengan manhaj telah ditentukan caleg-caleg PKS sudah melalui proses pengkaderan yang cukup panjang dan berjenjang. Mereka yang telah lulus pengkaderan akan diarahkan untuk menjadi calon anggota legislatif secara bertahap. Dapat dikatakan bahwa kaderisasi adalah wadah untuk membina pemahaman para kader bahwa politik merupakan suatu syariay Islam yang harus dijalankan oleh umat muslim untuk mewujudkan kemaslahatan agama.

Dalam sistem kepartaian di Indonesia, Partai Keadilan Sejahtera
(PKS) dikenal sebagai partai dakwah. Bagi PKS dakwah dapat ditegakkan secara utuh bila bertumpu pada dua sayap, yaitu sayap syar'iyah dan sayap kauniyah. Sayap syar'iyah bermakna bahawa segala dasar dan arah dakwah bersandar kepada aturan-aturan Allah SWT dan Rasulullah SAW sebagaimana yang tertulis dalam al-Quran dan asSunnah. Manakala sayap kauniyah adalah segala aturan, sifat, tabiat dan ketentuan yang terjadi di alam semesta yang merupakan sunnatullah. Dengan sayap syar'iyah, amal Islamik selalu berada pada jalan yang benar. Melalui sayap kauniyah, amal Islamik ini menjadi dinamis dan bersesuaian dengan tabiat kauniyah. Kedua-duanya dilihat sebagai saling melengkapi, kerana efektif dan dinamik amal Islamik akan tidak menentu arah dan tujuannya apabila tidak dipagari oleh syar'iyah.

Sebagai partai yang lahir dari rahim gerakan tarbiyah, kader-kader PKS sudah terbiasa dalam mengkaji dan mendiskusikan teks-teks keagamaan tradisional. Dalam perkembangannya, PKS juga mengembangkan perspektif tarbiyah yang lebih luas meliputi tarbiyyah nadzariyah (pendidikan norma dan teori Islam), tarbiyah ruhiyyah (pendidikan moral dan etika), 
Komunike, Volume XIII, No. 1 Juni 2021

tarbiyah maidaniyyah (pendidikan

praktek mobilisasi masa dan organisasi), tarbiyah fikriyyah(kajian pemikiran kritis, termasuk logika dan teori kritis), tarbiyah harakiyyah (pendidikan pengembangan organisasi dan training terkait mobilisasi partai politik).

c. Amar Ma'ruf Nahi Mungkar

Orientasi para tuan guru dalam terjun ke dunia politik adalah untukmenegakkan amar ma'ruf nahi munkar. Konsep amar ma'ruf nahi munkar inidiletakan dalam pengertian yang luas, yaitu pengawasan dan evaluasi. Dalam pandangan tuan guru, konsep ini memiliki peran signifikan, karena dalam kenyataannya tatanan sosial-politik yang ada banyak yang tidak sejalan dengan ajaran agama.

Karena itulah para tuan guru merasa perlu untuk terjun ke dalam dunia politik untukmewujudkan kontrol kekuasaan yang sewenang-wenang dan menyimpang dariaturan moral, hukum, maupun aturan agama.

Selain itu, konsep amar ma'ruf ini juga dipahami dalam cakupan dan pengertian yang luas, yaitu mewujudkan perbaikan sistem pendidikan, penegakan supremasi hukum, meningkatkan kesejahteraan rakyat, dan memprioritaskan pembangunan bagi

rakyat. Meskipun demikian, masuknya para tuan guru ke dunia politik tidak selalu membawa implikasi yang menggembirakan. Misalnya pesantren yang tak terurus dengan baik, ataupun fungsi-fungsi sosial-keagamaan tuan guru yang sedikit banyak terdegradasi. Dengan demikian, keterlibatan tuan guru dalam politik jika melihat dari kontek amar ma'ruf nahi mungkar adalah wajib sebagai wadah dakwah dan tuan guru mempunyai posisi yang strategis dalam masalah ini.

d. Membangun Partisifasi Politik Masyarakat

Tuan guru mempunyai peran yang sangat penting dalam rangka menggerakan partisipasi masyarakat dalam sebuah pilkada. Keberhasilan tuan guru dalam rangka menggerakan partisipasi masyarakat dalam pilkada di Lombok sangat ditentukan oleh kemampuan atau gaya dari tuan guru dalam memberikan orasi politiknya dalam kampanye, himbauan dan sarannya dalam mempengaruhi warga masyarakat atau juga sangat ditentukan oleh cara guru dalam menggunakan kewenangan sebagai pemimpin agama.

Politik sebenarnya tidak berbeda dengan upaya menata masyarakat, Melandasi masyarakat dengan akhlakul 
karimah, menggugah mereka dengan hilanah yang mulia, mempersatukan mereka dengan sikap persaudaraan dan kasih sayang. Politik juga bertujuan untuk meratakan keadilan, kesejahteraan, dan tolong menolong, menegakkan kepemimpinan yang mengabdi kepada kepentingan umat, mencintai dan dicintai umat, menata masyarakat berdasar hukum yang tidak berat sebelah, dan menegakkan martabat manusia yang mulia untuk membina perdamaian dan kemajuan yang bermanfaat.

Dengan demikian, maka peran tuan guru dengan partisipasipolitik publik mempunyai hubungan yang sangat erat dan tidak bisa dipisahkan,sebab apabila peran dari tuan guru semakin baik maka partisipasi politik jugaakan semakin meningkat.

Dalam proses pilkada langsung tentunya sangat dibutuhkan peran dari para tuan guru dalam meningkatkan partisipasi politik masyarakat, karenasesungguhnya tanpa disadari dimata masyarakat tokoh agama merupakan sosok yang paling disegani dan patut untuk diteladani. Realita yang terdapat dimasyarakat, Tokoh agama punya kharisma tersendiri yang dapat dan mampu merubah sifat, cara pandang bahkan tingkah laku seseorang untuk menjadi yanglebih baik. Dalam kaitannya dengannya pilkada langsung yang dilakukan di Lombok partisipasi politik masyarakat tidak terlepas dariperanan para tokoh agama dalam mengoptimalkan masyarakat untuk turut aktifdalam berpartisipasi terhadap pilkada langsung yang dilakukan.

Partisipasi masyarakat memerlukan upaya sosialisasi yang intensif agar potensi konflik yang membayanginya dapat diredam atau diminimalisir. Sejurus dengan upaya itu dibutuhkan partisipasi masyarakat agarsosialisasi itu berjalan optimal dan efektif, sehingga pada gilirannya masyarakat daerah dapat menggunakan hak memilih kandidat kepala daerah secara lebih rasional dan obyektif. Kegiatan seorang dalam partai dalam partai politikmerupakan suatu bentuk partisipasi politik. Partisipasi politik mencakup semua. Disinilah tokoh masyarakat semacam tuan guru dapat menggunakan perannya mendukung terpenuhinya apirasi politik masyarakat.

e. Mengembangkan Pondok Pesantren Pondok pesantren sebagai basis para tuan guru di Lombok mempunyai peran yang strategis dalam membentuk figur seorang tuan guru. Pada umumnya 
semakin besar suatu pondok pesantren maka semakin besar pula kapasitas seorang tuan guru. Yang menjadi tolak ukur besarnya pesantren adalah jumlah santri yang banyak dari berbagai daerah. Akan lebih besar lagi kalau berasal dari luar daerah NTB seperti bima, NTT, Bali, Kalimantan dan lain sebagainya.

Untuk mendukung pesantren yang besar pondok pesantren membutuhkan infrastruktur memadai dan tidak mungkin dapat tercapai dengan biaya pendidikan yang dikenakan kepada para santri. Pihak pondok pesantren umumnya mendapat sumbangan dari pemerintah melalui hubungan politik.

Oleh karena itu, bagi seorang tuan guru yang mengelola pondok pesantren keterlibatannya dalam politik praktik seakan menjadi sebuah keharusan untuk dapat mengakses danadana bantuan sosial untuk pengembangan pondok pesantren. Keterlibatan tuan guru dalam politik dalam rangka mengembangkan pondok pesantren, menurut pantauan peneliti jumlahnya siginifikan, hal ini umumnya berlaku pada pondok pesantren dengan jumlah siswa dan jamaah yang signifikan.

\section{Bentuk Keterlibatan Tuan Guru Dalam Politik}

Dalam masyarakat Lombok tuan guru menjadi sosok penting yang menjadi penuntun praktik beragama dan sekaligus menjadi tumpuan pemecahan problem kehidupan. Kedudukannya sebagai ahli agama menjadikannya orang yang sangat dipatuhi dan ditaati hampir dalam seluruh aspek kehidupan. Tingkat kepatuhan dan ketaatan tersebut seringkali didasarkan atas ketinggian ilmu dan kesalehan seorang tuan guru yang menjadi barometer penilaian dan pengakuan masyarakat.

Hampir seluruh problem kehidupan yang dihadapi masyarakat selalu meminta petunjuk dan jalan keluar kepada tuan guru. Dan petunjuk yang diberikan dalam seluruh persoalan kehidupan tersebut diyakini kebenarannya oleh masyarakat karena akan membawa keselamatan dunia dan akhirat. Tak terkecuali dalam politik, pilihan politik masyarakat selalu mengacu pada pilihan dan arahan politik tuan guru.

Tuan guru sebagai pemimpin informal tampil sebagai aktor politik paling menentukan dalam dinamika politik di Nusa Tenggara Barat dan Lombok pada khususnya. Rentetan even politik yang sudah berlangsung selalu 
menghadirkan pertarungan kekuatan tuan guru. Misalnya pemilihan umum legislatif di Kabupaten Lombok Tengah pada tahun 2004 yang menyuguhkan fragmentasi pilihan politik jamaah terhadap calon anggota legislatif sangat mudah dilacak dengan afiliasi politik tuan guru.

Peta kekuatan politik mudah terlihat dengan dominasi tuan guru dalam kekuatan politik tertentu, semakin banyak tuan guru yang tergabung dan mendukung kekuatan politik tertentu maka peta perpolitikan akan mudah terbaca. Loyalitas jamaah jelas menjadi faktor utama yang mengakibatkan dinamika politik tersebut bertumpu pada sosok seorang tuan guru. Dan bahkan pergeseran pilihan tuan guru terhadap partai politikpun ternyata tidak mengakibatkan bergesernya jumlah masa yang mendukung pilihan politik tuan guru.

Peta kekuatan politik yang dinamis dan bertumpu pada sosok tuan guru tidak lepas dari loyalitas yang terbangun antara jamaah dan tuan guru. Dalam konteks ini kemudian tuan guru sebagai elite agama mendominasi sikap dan pilihan politik yang harus diikuti oleh para jamaahnya. Para tuan guru tidak akan begitu sulit untuk memobilisasi massa untuk menggalang suara dalam even politik. Jika para tuan guru sudah menginstruksikan untuk menentukan sikap politik maka seluruh jamaah akan dengan mudah untuk mematuhinya tanpa bertanya terlebih dahulu terhadap sikap politik tersebut.

Dalam pilkada 2019, para tuan guru ikut ambil bagian mensukseskan pesta demokrasi itu. Ada beberapa bentuk partisifasi tuan guru dalam pilkada 2019, diantaranya:

a. Mencalonkan diri sebagai calon legislatif

Pemilihan legislatif tahan 2019 banyak diikuti oleh tuan guru, baik tuan guru kecil maupun tuan guru besar, baik tuan guru yunior maupun tuan guru senior bahkan ada beberapa calon legislatif yng sebelumnya bukan tuan guru,menaruhkan label tuan guru pada namanya pada saat pencalonan sebagai anggota legislatif.

Pencalonan tuan guru sebagai Calon Anggota Legislatif pada tahun 2019 adalah bentuk kiprah tuan tuan guru dalam politik praktis di Praya Lombok Tengah. Beberapa tuan guru yang menajdi calon anggota legislatif baik ditingkat daerah, provinsi maupun RI, berangkat dari keyakinan peluang untuk sukses sebagai anggota legislatif. 
Pencalonan tuan guru sebagai calon anggota legislatif, bukan hanya pada partai-partai berbasis Islam seperti PKS, PKB dan PPP, namun tersebar hampir diseluruh partai. Partai-partai memang membidik kalangan tuan guru sebagai penggerak massa sehingga ramai masyarakat memilih partai tersebut.

Hal itu secara langsung melibatkan elite pesantren, yakni kiai dan keluarganya atau ustad senior yang memiliki hubungan dengan kiai. Keterlibatan secara langsung memberikan peluang politik yang lebih besar bagi elite pesantren untuk mencapai jabatan poilitik yang lebih baik. Posisi tersebut diharapkan memberikan ruang politik untuk memperjuangkan aspirasi masyarakat dan kepentingan pesantren, karena jabatan-jabatan politik turut sebagai penentu kebijakan dan programprogram pembangunan.

b. Mencalonkan keluarga

Disamping tuan guru terlibat sebagai calon anggota legislatif, tuan guru juga terlibat dalam politik praktis dengan mencalonkan keluarga sebagai calon anggota legislatf, keluarga itu bisa istri, anak, keponakan atau saudara.
Sebagai bentuk dari dukungan terhadap calon anggota legislatif yang didukung, tuan guru melakukan sosialiasi melalui majlis-majlis taklim yang diasuhnya, melalui jaringan alumni pondok pesantren dan wali-wali murid.

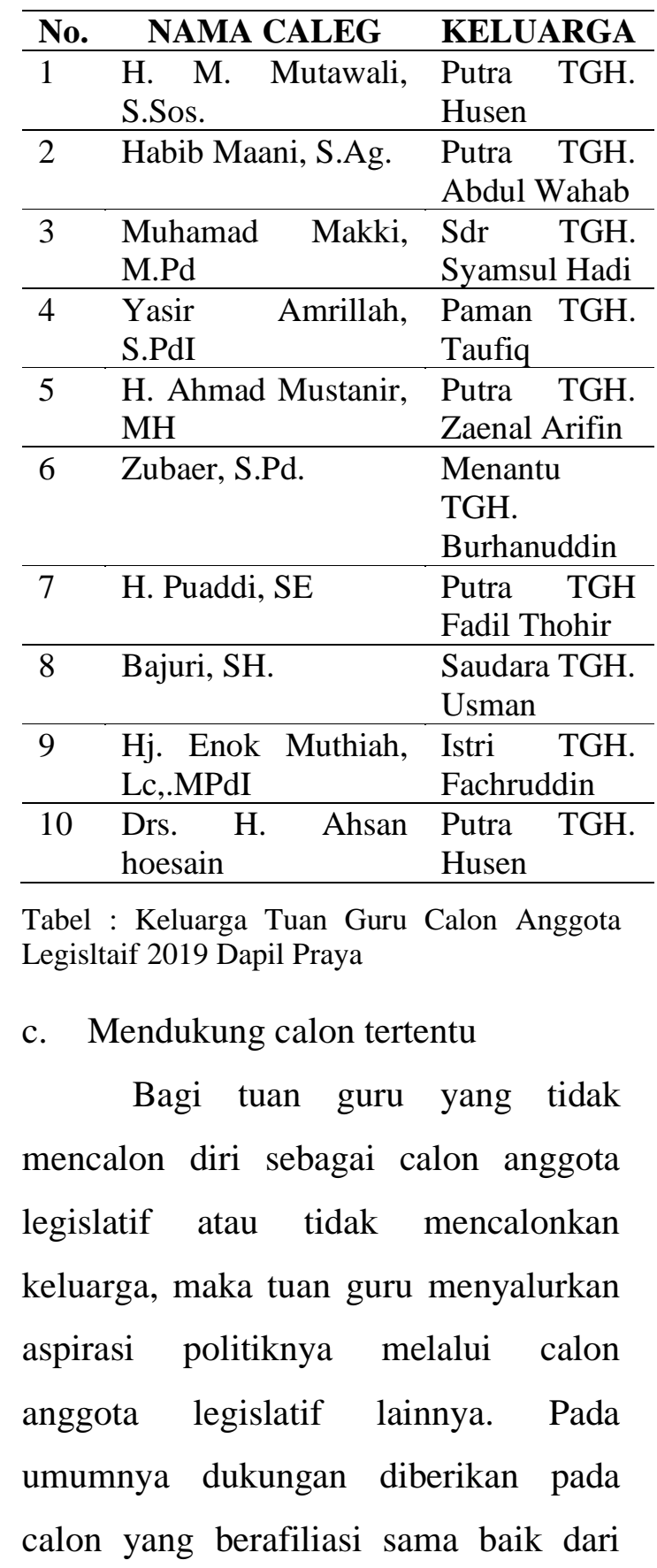


segi organisasi massa atau backround ideologi. Dalam prakteknya tuan guru yang berfialiasi di bawah organisasi Nahdlatul Wathan akan mendukung calon kader Nahdlatul Wathan dari partai yang direkomendasikan oleh pimpinan organisasi masyarakat tersebut.

Berdasarkan realita yang terjadi di Masyarakat, golongan ini didominasi oleh inkumben, posisinya sebagai inkumben memberikan peluang yang terbuka menyiapkan "amunisi" untuk menggalang dukugan.

Tuan guru banyak didatangi oleh calon-calon anggota dewan baik sebagai inkumben atau non inkumben untuk menggalang dukungan masyarakat. Sebagai imbalannya tuan guru diberikan "sumbangan" baik itu berupa dana atau bahan bangunan pondok pesantren, sebagai bentuk konsekwensi awal terhadap sebuah dukungan.

Model keterlibatan politik kiai yang kedua adalah sebagai legitimasi politik yang sering dimanifestasikan dalam bentuk restu politik pada partai atau tokoh politik tertentu yang berasal atau tidak berasal dari lingkungan pesantren. Hal seperti itu bagi banyak praktisi politik dianggap penting, sebab dalam sistem politik Indonesia yang ideologis dan tradisional, legitimasi keagamaan sangat dibutuhkan. Dan citra sebagai seorang Muslim yang baik,saleh, serta dekat dengan ulama turut menentukan elektabilitas seorang praktisi politik di hadapan pemilih Muslim. Berkaitan dengan itu, pesantren sering menerima "order" kunjungan politisi, calon anggota legislatif, atau komunitas partai politik tertentu yang sedang berkompetisi.

\section{E. KESIMPULAN}

Keterlibatan Tuan Guru di Praya Lombok Tengah dalam politik dilatarbelakangi oleh kapasitas dan perannya dalam masyarakat, namun kemudian peran bergeser ke arah "political oriented". Peran tuan guru tidak hanya sebagai muballigh akan tetapi juga sebagai actor politik praktis yang dikhawatirkan menjadikan dakwah sebagai peluang melakukan sosialisasi politik yang sarat dengan kepentingan politik. Adapun alasan-alasan tuan guru terjun kepolitik praktis adalah: 1) Menyalurkan aspirasi di masyarakat, 2) Mengembangkan lembaga-lembaga islam 3) Menegakkan amar makruf nahi mungkar, 4) Membangun partisipasi dan pendidikan politik terhadap masyarakat. 


\section{F. DAFTAR PUSTAKA}

Agus Dedi Putrawam, Dekarismatisasi Tuan Turu Di Pulau Lombok Nusa Tenggara Barat, In Right Jurnal Agama dan Hak Azazi Manusia Vol. 5, No. 2, Mei 2014.

Ahmad Asrori dkk, Dakwah dan Politik: Menakar Kontribusi Organisasi Islam Sayap Partai Politik Bagi Masyarakat Muslim Yogyakarta, Jurnal Dakwah, Vol. XIV, No. 1 Tahun 2013.

Ahsanul Rijal, Politik Tuan Turu Versus Politik Media "Pilpres 2019 di Lombok "Antara Dakwah dan Politik. Volume 16, No. 2, Juni 2019.

Andi Darmawan, Dialektika Dakwah, Politik dan Gerakan Keagamaan Kontemporer (Telaah Pemikiran Nasir al-Din al-Albani dan Pengaruhnya Terhadap Pembentukan Salafy Kontemporer) Jurnal Dakwah, Vol. XIV, No. 2 Tahun 2013.

Fahrurrozi, Budaya Pesantren Di Pulau Seribu Masjid, Lombok, KARSA: Jurnal Sosial dan Budaya Keislaman Vol. 23 No. 2, Desember 2015.
H. Sadi, Kiai Dan Politik: Mengintip Motif Kiai Nu (Nahdlatul Ulama) Dalam Pemilu 2009 Di Glenmore Kabupaten Banyuwangi Khazanah Pendidikan Jurnal Ilmiah

Jamaludin, Sejarah Sosial Islam di Lombok Tahun 1740-1935. Kependidikan, Vol. X, No. 1 (September 2016)

Nasution, Metode Penelitian Naturalistik-Kualitatif (Bandung: Tarsito, 1992.)

Soeryono Soekanto, Pengantar Penelitian Hukum, (UI Press, Jakarta, 1986).

Titin Yuniartin, Identitas Politik Partai Keadilan Sejahtera, KOMUNIKA: Jurnal Dakwah dan Komunikasi Vol. 12, No. 2, Juli - Desember 2018 .

Warjio, Falsafah dan Strategi Politik Dakwah PKS, Jurnal POLITEIA|Vol.3|No.2|Juli 2011.

Winengan, Seni Mengelola Dakwah, (LP2M UIN Mataram, 2018) 